\title{
Identification of the 37kda Annexin-A1 Protein in Tears of Normal Subjects and Association of its 33kda Inactive Form with Active Vernal Keratoconjunctivitis Patients
}

\author{
Samia Yazid ${ }^{1 *}$, Andrea Leonardi², Virginia Calder ${ }^{3}$ and Roderick Flower ${ }^{1}$ \\ ${ }^{1}$ William Harvey Research Institute, Queen Mary University, London, UK \\ ${ }^{2}$ University of Padua, Italy \\ ${ }^{3}$ UCL, University of Ophthalmology, London, UK
}

\begin{abstract}
Background: Annexin-A1 (Anx-A1) is a glucocorticoid-regulated 37kDa protein with powerful anti-inflammatory actions: enhanced release from target cells occurs following addition of the anti-allergic cromone drugs. Anx-A1 is inactivated by proteolytic cleavage of the $\mathrm{N}$-terminus and increased amounts of the cleaved $33 \mathrm{kDa}$ product correlate with inflammatory responses.
\end{abstract} (VKC).

Aim: To investigate if Anx-A1 is detectable in human tear specimens from patients with vernal keratoconjunctivitis

Methods: Tear specimens were collected from patients affected by active VKC $(n=23)$ before and after therapy with Alomide (equivalent to Lodoxamide) $0.1 \%(n=11)$ for 10 daysand non-inflammatory control tear specimens from healthy volunteers $(n=17)$ who gave informed consent. Anx-A1 protein levels were measured by ELISA and by Western blotting.

Results: In cell-free tear specimens from healthy donors, the concentration of Anx-A1 was $433.6 \pm 54.3 \mathrm{pg} /$ $\mathrm{ml}(\mathrm{n}=17)$ and $>90 \%$ was in the intact form. In tears from VKC patients however, total Anx-A1 increased to 1908 $\pm 319.3 \mathrm{pg} / \mathrm{ml}(\mathrm{n}=23 ; \mathrm{p}<0.05)$ but only $48 \%(921.5 \pm 193.5 \mathrm{pg} / \mathrm{ml})$ of this was the intact biologically active species. Proteolytic cleavage of the protein was reduced in the group treated with Alomide $(>80 \%$ is intact form, $n=11$, $\mathrm{p}<0.01)$.

Conclusion: Anx-A1 is constitutively present in normal human tears and is proteolytically cleaved to inactivation during chronic allergic disease. Alomide treatment decreased the proportion of cleaved protein in VKC patients, and this is perhaps related to its therapeutic action.

Keywords: Annexin-A1; Tears; VKC; Ocular allergic disease

Abbreviations: Anx-A1 (Annexin-A1); VKC (Vernalkeratoconjunctivitis)

\section{Introduction}

Anx-A1 is a $37 \mathrm{kDa}, \mathrm{Ca} 2+-$ phospholipid binding protein, which mimics acute glucocorticoid anti-inflammatory effects in many animal models of acute and chronic inflammation. Recently, cromones or mast cell stabilizers have been shown to also exert their anti-allergic and antiinflammatory activities through the secretion of Anx-A1 protein. This can inhibit eicosanoid production in a pro-monocytic U937 cell line [1], inhibit leukocyte recruitment in a model of ischaemia-reperfusion [2] and inhibit histamine release in IgE-crosslinked human mast cells (data unpublished). Glucocorticoids and mast cell stabilizers are mainstream drugs used in the treatment and prevention of allergy.

There are 12 members of the annexin superfamily in vertebrates and each is characterized and distinguished by its unique N-terminal region. In the case of Anx-A1, this harbours several proteolytic motifs and an N-terminal truncated moiety is a commonly found species in inflammatory fluids [3]. Proteolysis of the N-terminal domain profoundly modifies the physical and biological properties of the protein. Indeed, degradation of Anx-A1 is thought to result in chronic inflammation and unresolved inflammatory conditions seen for example in Cystic Fibrosis patients or in bronchoalveolar lavage fluids from healthy smokers $[4,5]$, where a cleaved form $(33 \mathrm{kDa})$ of Anx-A1 is predominantly found instead of intact $(37 \mathrm{kDa})$. In Wegener's granulomatosis, Anx-A1 is cleaved by a serine protease, proteinase-3, released from activated PMN [6]. Taken together, these studies demonstrate that Anx-A1 can be functionally impaired during chronic inflammation, and therefore low levels of intact, or increased levels of the cleaved Anx-A1, can be a marker or predictor of inflammatory disease.

Allergic conjunctivitis (AC) is a common condition that affects the quality of life for millions of sufferers. This ocular process is associated with IgE-mediated conjunctival inflammation with mast cells being the predominant effector cells [7]. Indeed, mast cell mediators such as histamine, proteases and platelet activating factor are thought to initiate the early phase of the allergic reaction whilst cytokines, leukotrienes and chemokines contribute to the late phase, which is associated with infiltration and migration of leukocytes such as neutrophils and eosinophils to the ocular surface $[8,9]$. There are other much less

${ }^{*}$ Corresponding author: Dr. SamiaYazid, PhD, Molecular Therapy Department Institute of Ophthalmology, University College London, 11/43 Bath street, London, UK, EC1V 9EL, E-mail: s.yazid@ucl.ac.uk

Received November 26, 2011; Accepted January 21, 2012; Published January 26, 2012

Citation: Yazid S, Leonardi A Calder V Flower R (2012) Identification of the 37kda Annexin-A1 Protein in Tears of Normal Subjects and Association of its 33kda Inactive Form with Active Vernal Kerato Conjunctivitis Patients. J Aller Ther S7:007. doi:10.4172/2155-6121.S7-007

Copyright: (C) 2012 Yazid S, et al. This is an open-access article distributed unde the terms of the Creative Commons Attribution License, which permits unrestricted use, distribution, and reproduction in any medium, provided the original author and source are credited. 
Citation: Yazid S, Leonardi A, Calder V, Flower R (2012) Identification of the 37kda Annexin-A1 Protein in Tears of Normal Subjects and Association of its 33kda Inactive Form with Active Vernal Kerato Conjunctivitis Patients. J Aller Ther S7:007. doi:10.4172/2155-6121.S7-007

common, but more clinically severe allergic eye diseases in which the use of immunosuppressives such as steroids and cyclosporin $\mathrm{A}$ are required to control the immune-mediated disease processes. The two main diseases are vernal keratoconjunctivitis $(\mathrm{VKC})$ and atopic keratoconjunctivitis (AKC) and these tend to affect individuals who already have an allergic disease such as chronic asthma or eczema. The ocular symptoms include photophobia, pain, redness and the formation of giant papillae in the conjunctival tissues which are heavily infiltrated with CD4+ T lymphocytes and eosinophils. Both diseases can severely compromise the cornea with ulcers and scarring that can cause visual impairment by immunopathogenic mechanisms involving a combination of IgE- and T-cell- mediated responses [10,11]. Mast cells are not the primary effector cells in these more severe forms of the disease, and mast cell-targeted therapy alone is ineffective in controlling this inflammation. Nevertheless mast cells are activated and are thought to contribute to the inflammation due to their secretion of proinflammatory mediators. Mast cell targeted therapy is often used as an adjunct therapy during exacerbations.

The majority of individuals with mild ocular allergy are treated with a topical application of mast cell stabilizing or antihistamine drugs to relieve the symptoms of immediate hypersensitivity- redness, itching and tearing. For those individuals with more clinically severe disease, topical application of steroids and cyclosporin $\mathrm{A}$, is required, and both of the immunosuppressives have serious side-effects in the eye.

In the present study, we have observed Anx-A1 to be highly expressed in normal human tears. Therefore, we wanted to evaluate its potential role in patients with chronic ocular allergic diseases such as VKC.

\section{Methods}

\section{Subjects}

A total of 51 subjects were used for these experiments. After clinical evaluation of ocular signs and symptoms, tear samples were collected from patients who presented at the Institute of Clinical Ophthalmology, University of Padua in Italy, with active new referrals or with a reactivation of the disease: $23 \mathrm{VKC}$ patients with active disease (mean age, $10.4 \pm 5.9$ years; range, $8-24), 11$ treated disease with Lodoxamide $0.1 \%$ (mean age, $11.6 \pm 5$ years; range, $7-22$ ) and 17 healthy, non-atopic control subjects (mean age, $16.5 \pm 5$; range, 10-24). All patients with active VKC were free from medication for at least 5 days.

Written informed consent was obtained from all participants. Research followed the Tenets of the Declaration of Helsinki and Institutional Review Board approval was obtained.

\section{Tear collection}

Using a capillary micro-pipette, tears were gently collected from the external canthus (avoiding the tear reflex as much as possible) and transferred to Eppendorf tubes. 50-100 $\mu \mathrm{l}$ of tears were collected from each subject. Tears were collected from the most affected eye or pooled from both eyes if the condition was clinically symmetrical. Tear fluid was centrifuged at $2000 \mathrm{rpm}$ for 10 minutes to remove cell debris. The supernatants were then stored at $-80^{\circ} \mathrm{C}$ for subsequent detection of Anx-A1 by Western Blotting and ELISA in each patient tears.

\section{Detection and characterization of Anx-A1 by western blotting}

The total tear protein was determined using a micro-BSA protein assay (Pierce, UK) and analysed by conventional western blotting techniques. Immunodetection was accomplished using different antibodies recognizing either the full-length Anx-A1 protein, (polyclonal anti-Anx-A1 antibody; 1:1000, Invitrogen, Paisley, UK) orlactoferrin (monoclonal anti-lactoferrin; 1:5000, Sigma-Aldrich, Poole, UK). A horseradish peroxidase-conjugated secondary antibody (1:2000, Sigma-Aldrich, Poole, UK) detected bands related to the proteins of interest and these were revealed by enhanced chemiluminescence.

\section{Quantification of Anx-A1 by ELISA}

A 96-well plate was coated at $4^{\circ} \mathrm{C}$ overnight with $10 \mathrm{mg} /$ well of a murine monoclonal anti-Anx-A1 antibody [12] in coating buffer [50 $\mathrm{mM} \mathrm{Na} \mathrm{CO}_{3}$ and $50 \mathrm{mM} \mathrm{NaHCO}$ ( $\mathrm{pH}$ 9.6)], washed, and blocked with $1 \%$ FCS in coating buffer for $1 \mathrm{~h}$ at $37^{\circ} \mathrm{C}$. Samples and a standard series of hrAnx-A1[13] were then added to the plate in triplicates and incubated for $1 \mathrm{~h}$ at $37^{\circ} \mathrm{C}$ in incubation buffer $(50 \mathrm{mM}$ Tris- $\mathrm{HCl}, 100$ $\mathrm{mM} \mathrm{NaCl}, 1 \mathrm{mM}$ EDTA, 1\% FCS, and 0.05\% Tween 20). Wells were washed, and incubated for $1 \mathrm{~h}$ at $37^{\circ} \mathrm{C}$ with either a rabbit anti-Anx-A1 polyclonal antibody, to detect species of the protein (1:1000; Invitrogen U.K.) or a sheep anti-N-terminus-Anx-A1 polyclonal antibody [14] to detect only the intact form (with N-terminus) of the protein (1:1000). Wells were again washed and incubated either with HRP-conjugated sheep anti-rabbit polyclonal antiserum (Serotec; diluted 1:500 in incubation buffer) for $1 \mathrm{~h}$ at $37^{\circ} \mathrm{C}$. Plates were washed and incubated with 3,39,5,59-tetramethylbenzidine substrate (Sigma-Aldrich) for 10 min at room temperature, with the reaction being stopped by addition of $0.5 \mathrm{M} \mathrm{H}_{2} \mathrm{SO}_{4}$. A spectrophotometer (Versamax Microplate Reader; MDS Analytical Technologies, Sunnyvale, CA) was then used to read absorbance at $450 \mathrm{~nm}$, with plate correction being made at $570 \mathrm{~nm}$.

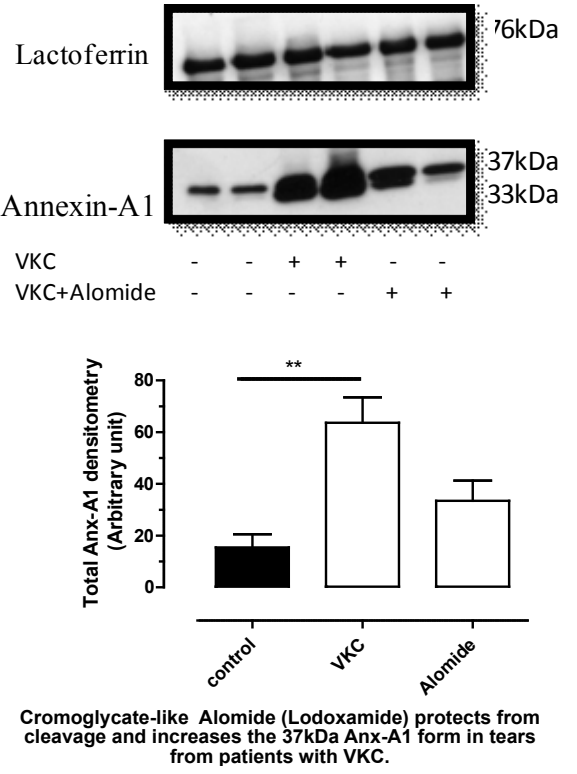

Figure 1: Characterization of the $37 \mathrm{kDa}$ biologically active form of AnxA1 in healthy controls and the $33 \mathrm{kDa}$ proteolytically cleaved form of Anx-A1 in VKC patients

(A) Representative blot of tear specimens collected from healthy donors, non-treated patients with VKC and Lodoxomide treated VKC individuals. Lactoferrin was used as positive control in our assay since its constitutive expression in tear film. Anx-A1 $37 \mathrm{kDa}$ is highly expressed in control group, while a $33 \mathrm{kDa}$ band appears in VKC tear specimens and interestingly abrogated in patients treated with Lodoxomide. (B) Densitometry of $n=17$ control group, $n=23$ VKC group and $n=12$ Lodoxomide treated group showing a significantincreasein the amount of the cleaved (inactive) form of Anx-A1 in VKC patients compare to controls $(p<0.01)$. This cleavage is protected in patients treated with Lodoxomide. 
Citation: Yazid S, Leonardi A, Calder V, Flower R (2012) Identification of the 37kda Annexin-A1 Protein in Tears of Normal Subjects and Association of its 33kda Inactive Form with Active Vernal Kerato Conjunctivitis Patients. J Aller Ther S7:007. doi:10.4172/2155-6121.S7-007

Page 3 of 4

\section{Statistical analysis}

Values are expressed as mean \pm SEM of $n$ observations. Statistical differences between the treated groups were assessed byanalysis of variance (ANOVA) followed by Bonferroni's test for intergroup comparisons. Athreshold $p$ value $\leq 0.05$ was taken as significant.

\section{Results}

Twenty-three consecutive patients with VKC (mean age, $10.4 \pm 5.9$ years; range, 8-24), 11 VKC patients treated with Alomide (mean age, $11.6 \pm 5$ years; range, $7-22$ ) and 17 normal subjects were included in the study. Patients with VKC were in an active disease phase and had been free of treatment for at least 5 days. The control group was age matched (mean age, $16.5 \pm 5$; range, 10-24). No subject in the control group used contact lenses or had any inflammatory signs and symptoms.

We have identified and characterized, for the first time, the presence of Anx-A1 protein in human tear fluid specimens. While Western blotting revealed the existence of the $37 \mathrm{kDa}$ active form of the protein in control group, VKC non-treated group showed an increase in both the full length $37 \mathrm{kDa}$ and truncated $33 \mathrm{kDa}$ inactive form of the protein (Figure 1). Interestingly, treatment with Alomide, a cromoglycate-like drug, showed, in the VKC group a decrease in the proportion of Anx-A1 truncated product. Despite the small volumes of tears obtained from the donors, we managed to also quantify Anx-A1 level by ELISA in each patient tears collected. Control group contained
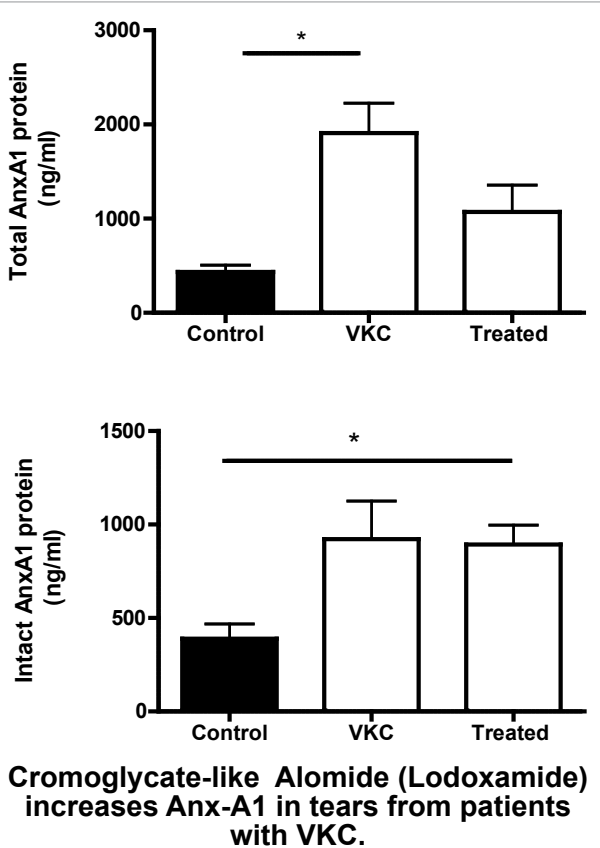

Figure 2: Quantification by ELISA of Anx-A1 level in human tear subjects

(A) By using a specific anti-Anx-A1 antibody targeting the full-length of the protein, we were able to observe increase amounts of the protein in VKC patients compare to healthy controls. Interestingly, Anx-A1 level expression is decreased in VKC-treated patients with Lodoxomide. (B) By using a specific anti-Anx-A1 antibody targeting the $\mathrm{N}$-terminal of the protein, we could measure the first amino acids that retain the entire intact $\mathrm{N}$-terminal region. Interestingly, we could observe a small amount increase of the $\mathrm{N}$-terminal region of Anx-A1 in VKC patients compare to the total measured (see (A)). However, VKC patients treated with Lodoxomide could show a same amount in the increase of N-terminal Anx-A1 compare to total (A). ${ }^{*} p<0.05$ ANOVA/ Bonferroni test. ( $n=17$ control group, $n=23$ VKC group and $n=11$ Lodoxomide treated group).

\begin{tabular}{|l|l|l|l|} 
& $\begin{array}{l}\text { Intact } \\
\text { Anx-A1 expression } \\
(\mathbf{p g} / \mathbf{m l})\end{array}$ & $\begin{array}{l}\text { Total Anx-A1 } \\
\text { expression } \\
\mathbf{( p g / m l )}\end{array}$ & $\begin{array}{l}\text { Total Anx-A1 } \\
\text { expression } \\
\mathbf{( p g / m l})\end{array}$ \\
\hline Control $(n=17)$ & $381 \pm 66$ & $433 \pm 90$ & $0.9 \pm 0.7$ \\
\hline VKC $(n=23)$ & $921 \pm 203$ & $1908 \pm 320$ & $0.48 \pm 0.6$ \\
\hline Alomide $(n=11)$ & $893.7 \pm 92$ & $893.7 \pm 92$ & $0.8 \pm 0.4$ \\
\hline
\end{tabular}

Table 1: Ratio of Intact Anx-A1 /Total Anx-A1

Table summarising ELISA results illustrated in Figure 2 in which total or full length protein Anx-A1 in tear specimens was detected using rabbit anti-Anx-A1 polyclonal antibody while intact Anx-A1 form (with $\mathrm{N}$-terminus) was detected usinga sheep anti-N-terminus-Anx-A1 polyclonal antibody.

easily detectable amounts of Anx-A1 protein $(433 \pm 90 \mathrm{pg} / \mathrm{ml}$, Figure 2 ); this latter corresponding to about $90 \%$ of its intact form (Table 1). In untreated VKC group, total Anx-A1 tear levels were significantly increased $(1908 \pm 320 \mathrm{pg} / \mathrm{ml}, \mathrm{p}<0.05)$ compared with normal subjects (Figure 2). However, the use of an antibody detecting the $\mathrm{N}$-terminal domain of the protein, allowed us to observe that the increase amount of Anx-A1 in VKC patients is partly due to an increase in the cleaved form of the protein confirming the results found by Western blotting. Forty-eight percent of the protein was in the intact active form (Table $1)$.

\section{Discussion}

VKC is a recurrent or chronic ocular allergic disease that affects mostly children and young adults. Understanding and treating $\mathrm{VKC}$ has been a challenge for ophthalmologists since the pathogenesis is unclear and anti-allergic therapy is often unsuccessful. Numerous studies have investigated role of the multiple cytokines and chemokines in tears involved in the development of different ocular pathologies [15-17]. It is well established to be a Th2 cytokine cell-mediated disease with IL- 4 and IL-13 being the most abundant, although some Th1 cytokines such as IFN- $\gamma$ have shown to also be elevated compared to normal tear specimens. The former is attributed, in part, to tissue remodelling and the formation of papillae characteristic of this disease. Another feature ascribed to VKC is the increase of mast cells, neutrophils, eosinophils and monocytes in the conjunctival tissues [18,19]. Therefore understanding the complex interactions and cross talk between cells, cytokines and other mediators has been important for the development of new therapies. More recently, we have broadened the investigation on the existent proteins that constitute the tear film in order to understand the mechanism of action of topical ocular therapies as well as discovering new therapeutic targets.

Anx-A1 is highly expressed in most cell types of the myeloid lineage. During the course of tissue injury, the endogenous protein is rapidly secreted and binds to the formyl-peptide receptor- FPRfamily [20] to exert downstream its anti-inflammatory effect. In this study, we have for the first time identified Anx-A1 proteinin human tears. We observed, using Western Blotting and ELISA approaches, an increase of the $37 \mathrm{kDa}$ form of Anx-A1 protein in tears of $\mathrm{VKC}$ subjects compared to controls which can be explained by the rapid secretion of the Anx-A1 cytoplasmic pool from activated leukocytes recruited to the conjunctival tissue. Interestingly, we additionally detected a 33 $\mathrm{kDa}$ band corresponding to Anx-A1 truncated form, in a ratio 1:2 over the $37 \mathrm{kDa}$ in patients with the disease. Cleavage of Anx-A1 has been characterized and implicated in many chronic inflammatory diseases $[6,21,22]$, where serine proteases released by neutrophils, such as elastase [23] and proteinase 3 [6], are responsible. Because of the limited volume of tear samples we collected, we were unable to measure levels of serine protease in those patients in our study. However, it has been demonstrated that VKC subjects have increased concentration of 
Citation: Yazid S, Leonardi A, Calder V, Flower R (2012) Identification of the 37kda Annexin-A1 Protein in Tears of Normal Subjects and Association of its 33kda Inactive Form with Active Vernal Kerato Conjunctivitis Patients. J Aller Ther S7:007. doi:10.4172/2155-6121.S7-007

neutrophil-derived proteases such as elastase [19]. Therefore, consistent with previous studies, proteolytic cleavage of Anx-A1 associated with $\mathrm{VKC}$ can be explained by the high level of expression of serine proteases released by leukocytes infiltrating the conjunctival tissue including neutrophils and mast cells.

Finally, we screened VKC patients treated with Alomide, a dualfunction drug that can inhibit mast cells from degranulating as well as leukocyte recruitment. Surprisingly, we observed that the Anx-A1 full length protein is protected from proteolytic cleavage with a pattern of expression closer to that seen in control tears. This suggests a role for Alomide in inhibiting serine proteases or to interact directly with Anx-A1 protein enhancing a conformational change in which the $\mathrm{N}$-terminal domain is not exposed, and therefore protected from any possible proteolysis.

In conclusion, our study reveals that the presence of the truncated form of Anx-A1 is correlated with the clinical activity of VKC.

\section{Acknowledgment}

We acknowledge the support of the Wellcome Trust (Grant No. 085903/Z/08).

\section{References}

1. Yazid S, Solito E, Christian H, McArthur S, Goulding N, et al. (2009) Cromoglycate drugs suppress eicosanoid generation in U937 cells by promoting the release of Anx-A1. Biochem Pharmacol 77: 1814-1826.

2. Yazid S, Leoni G, Getting SJ, Cooper D, Solito E, et al. (2010) Antiallergic cromones inhibit neutrophil recruitment onto vascular endothelium via annexin-A1 mobilization. Arterioscler Thromb Vasc Biol 30: 1718-1724.

3. Liu L, Fisher AB, Zimmerman UJ (1995) Regulation of annexin I by proteolysis in rat alveolar epithelial type II cells. Biochemistry and molecular biology international 36: 373-381.

4. Tsao FH, Meyer KC, Chen X, Rosenthal NS, Hu J (1998) Degradation of annexin I in bronchoalveolar lavage fluid from patients with cystic fibrosis. Am J Respir Cell Mol Biol 18: 120-128.

5. Vishwanatha JK, Davis RG, Rubinstein I, Floreani A (1998) Annexin I degradation in bronchoalveolar lavage fluids from healthy smokers: a possible mechanism of inflammation. Clin Cancer Res 4: 2559-2564.

6. Vong L, D'Acquisto F, Pederzoli-Ribeil M, Lavagno L, Flower RJ, et al. (2007) Annexin 1 cleavage in activated neutrophils: a pivotal role for proteinase 3 . J Biol Chem 282: 29998-30004.

7. Fukuda K, Ohbayashi M, Morohoshi K, Zhang L, Liu FT, et al. (2009) Critical role of IgE-dependent mast cell activation in a murine model of allergic conjunctivitis. J Allergy Clin Immunol 124: 827-833 e2.

8. Liu G, Keane-Myers A, Miyazaki D, Tai A, Ono SJ (1999) Molecular and cellular aspects of allergic conjunctivitis. Chem Immunol 73: 39-58.

9. Miyazaki D, Tominaga T, Yakura K, Kuo CH, Komatsu N, et al. (2008) Conjunctival mast cell as a mediator of eosinophilic response in ocular allergy. Mol Vis 14: 1525-1532.

10. Calder VL, Jolly G, Hingorani M, Adamson P, Leonardi A, et al. (1999) Cytokine production and mRNA expression by conjunctival T-cell lines in chronic allergic eye disease. Clin Exp Allergy 29: 1214-1222.

11. Leonardi A, Fregona IA, Plebani M, Secchi AG, Calder VL (2006) Th1- and Th2-type cytokines in chronic ocular allergy. Graefes Arch Clin Exp Ophthalmol 244: $1240-1245$
12. Pepinsky RB, Sinclair LK, Dougas I, Liang CM, Lawton P, et al. (1990) Monoclonal antibodies to lipocortin-1 as probes for biological function. FEBS Lett 261: 247-252.

13. Lim LH, Solito E, Russo-Marie F, Flower RJ, Perretti M (1998) Promoting detachment of neutrophils adherent to murine postcapillary venules to contro inflammation: effect of lipocortin 1. Proc Natl Acad Sci USA 95: 14535-14539.

14. Smith SF, Goulding NJ, Godolphin JL, Tetley TD, Roberts CM, et al. (1990) An assay for the assessment of lipocortin 1 levels in human lung lavage fluid. $J$ Immunol Methods 131: 119-125.

15. Leonardi A, Curnow SJ, Zhan H, Calder VL (2006) Multiple cytokines in human tear specimens in seasonal and chronic allergic eye disease and in conjunctival fibroblast cultures. Clin Exp Allergy 36: 777-784

16. Leonardi A, Sathe S, Bortolotti M, Beaton A, Sack R (2009) Cytokines, matrix metalloproteases, angiogenic and growth factors in tears of normal subjects and vernal keratoconjunctivitis patients. Allergy 64: 710-717.

17. Bonini S, Lambiase A, Sgrulletta R (2003) Allergic chronic inflammation of the ocular surface in vernal keratoconjunctivitis. Curr Opin Allergy Clin Immunol 3 : 381-387.

18. Trocme SD, Leiferman KM, George T, Bonini S, Foster CS, et al. (2003) Neutrophil and eosinophil participation in atopic and vernal keratoconjunctivitis. Curr Eye Res 26: 319-325.

19. Leonardi A, Borghesan F, Faggian D, Depaoli M, Secchi AG, et al. (2000) Tear and serum soluble leukocyte activation markers in conjunctival allergic diseases. Am J Ophthalmol 129: 151-158.

20. Dufton N, Hannon R, Brancaleone V, Dalli J, Patel HB, et al. (2010) Antiinflammatory role of the murine formyl-peptide receptor 2: ligand-specific effects on leukocyte responses and experimental inflammation. J Immunol 184: 2611-2619.

21. Smith SF, Tetley TD, Guz A, Flower RJ (1990) Detection of lipocortin 1 in human lung lavage fluid: lipocortin degradation as a possible proteolytic mechanism in the control of inflammatory mediators and inflammation. Environ Health Perspect 85: 135-144.

22. Kurosu K, Takiguchi Y, Okada O, Yumoto N, Sakao S, et al. (2008) Identification of annexin 1 as a novel autoantigen in acute exacerbation of idiopathic pulmonary fibrosis, J Immunol 181: 756-767.

23. Rescher U, Goebeler V, Wilbers A, Gerke V (2006) Proteolytic cleavage of annexin 1 by human leukocyte elastase. Biochim Biophys Acta 1763: 1320 1324. 